\title{
DETERMINATION OF AREA AND VOLUME FROM DREDGED GEODATA SET
}

\author{
M. O. Ekun ${ }^{1}$, R. Ehigiator-Irughe ${ }^{2,}{ }^{*}$ and E. S.Okonofua ${ }^{3}$ \\ 1, 2,3DEPARTMENT OF GEOMATICS, FACULTY OF ENVIRONMENTAL SCIENCES, UNIVERSITY OF BENIN, Edo STATE, NIGERIA \\ Email addresses: ${ }^{1}$ mercy.ekun@uniben.edu, ${ }^{2}$ raphael.ehigiator@uniben.edu, \\ 3 ehizonomhen.okonofua@uniben.edu
}

\begin{abstract}
Dredging is a routine process necessary along waterways. This should be conducted in such a way that the quantity or volume of dredged materials can be determined for the purpose of costing and extent of the dredging. Therefore, the aim of this study is to compute the volume or stockpile of dredged materials using geospatial data. In order to obtain the geospatial data needed for the computation of the volume of the excavated material, pre-and postdredged surveys of the study area were carried out. The three dimensional surfaces of both pre- and post-dredged surveys were produced from the acquired geospatial data. The volume of the stockpile computed from the pre- and post-dredged surveys is approximately $9732 \mathrm{~m}^{3}$. The contour map and TIN were also produced.
\end{abstract}

Keywords: dredging, pre-dredged, area, volume, navigation

\section{INTRODUCTION}

Most human's activities, such as, recreations, transportations, oil and gas industries, and so on, revolve around the aquatic environments. These aquatic environments also house large numbers of organisms. To preserve these aquatic habitats, proper and regular maintenance of the water body through dredging activities is very important. Dredging is a routine process necessary for desalting water ways, wellhead access, slots etc. This is because these channels and harbours are often filled with sediments and contaminants resulting from natural and manmade impacts on our environment. The major focus of dredging is to maintain or improve the depth of water for navigation purposes in order to provide a safe passage for ships and cargos etc. Dredging can also be carried out for the purpose of land reclamation, excavation of material, stock piling, construction purposes, and so on. Dredging or excavation remedies can also be used to remove contaminated sediment from freshwater or marine water bodies in order to reduce risks to human health and the environment [1]. Dredging is also performed to reduce the exposure of fish, wildlife, and people to contaminants and to prevent the spread of contaminants to other areas of the water body [2]. This environmental dredging is often necessary because water bodies in and around cities and industrial areas are frequently contaminated with a variety of pollutants. The contamination in these sediments can also directly affect the environment, harm aquatic organisms or accumulate in their tissues and have adverse effect on humans' health when consumed. More so, dredged materials are used in building constructions, which become necessary as a result of fast increase of population [3].

Dredged materials are to be properly managed and disposed of in order to prevent its adverse effects on the environment as well as on humans. This is often approved and regulated by the governments at federals, states, and local governments' levels, as well as by private entities such as port authorities. For example, the United States Army Corps of Engineers (USACE) issues permits for the disposal of dredged material while the United States Environmental Protection Agency (USEPA) provides oversight and authorization for the disposal of dredged materials [1]. In Nigeria, National Inlands Waterways (NIWA) is the federal regulatory body for the capital and maintenance of dredging while Lagos State Ministry of Waterfront Infrastructure Development is the regulatory body in Lagos State [4, 5]. 
The primary aim of dredging is to maintain the depth of the waterway in order to improve navigation channels. Other benefits of dredging include but not limited to the following [6]:

* To deepen and maintain waterways, shipping channels and ports.

* To create and maintain beaches.

* To excavate harbours and build docks, terminals and piers

* To reclaim land

* To restore aquatic and wetland habitants

* To excavate pipeline, cable and tunnel trenches

* To mine ores or aggregate.

* Creating slot access for wellhead.

* Stock piling.

\section{STUDY AREA}

The project area is located in OMLs 43 and 45 in Burutu Local Government Area of Delta State of Nigeria. It is bounded approximately by geographical coordinate of $5^{0} 11^{\prime} 47^{\prime \prime} \mathrm{N}$ and $5^{0} 47^{\prime} 20^{\prime \prime} \mathrm{E}$ to $5^{0} 11^{\prime}$ $53^{\prime \prime} \mathrm{N}$ and $5^{0} 47^{\prime} 24^{\prime \prime} \mathrm{E}$. The entire area features meandering creeks and mangrove swamp. The land terrain is covered by mangrove forest. The area has a humid tropical climate characterized by high rainfall and high temperature. The area is influenced by two climatic periods, the dry and wet seasons. The dry season is experienced between November and March, while the wet season begins in April and ends in October and is typified by southwest trade winds laden with moisture blowing across the Atlantic Ocean.

\section{DREDGING PROCESS}

The three types of dredging are the navigational, constructional and environmental dredging [7]. The purpose of navigation dredging is to enlarge or deepen the aquatic highways for easy navigation. In environmental dredging, dredged materials are used for the creation or restoration of habitats (beach nourishment) and for remediation or clean-up i.e. the removal of contaminated sediments. In constructional dredging, dredged sands and gravels are used as construction materials for buildings and land reclamation projects.

Dredges or dredgers are the equipment used in dredging. Dredgers are broadly classified into two categories; these are mechanical dredges and hydraulic suction dredges, which work on the principle of adding large amounts of process water to change the original structure of the sediments. Other dredgers which do not fit in to the above two categories are Siphon dredges, pneumatic dredges[8].The performance of dredging equipment depends, in part, on the sediment properties[9].An ultrasonic flow meter, Differential Global Positioning System (DGPS) equipment, and a computerized positioning system, such as HYPACK Survey Navigation Software, can also be used alongside with the dredge in order to allow the dredge operator to be able to control and maintain the positioning as well as the progress rate. The incorporation of HYPACK software with kinematic differential Global Positioning System (DGPS) can also make automated tide reading and computation possible.

A well plan site investigation, which may include subsurface and geophysical investigations, Environmental Impact Assessment (EIA) and Environmental Evaluation Report (EER), is very necessary in order to understand the site conditions and to be able to successfully execute the project without causing more harm to the environment. The importance of an office reconnaissance cannot be underestimated also in dredging because the volume of sediment to be dredged can be calculated at the preliminary stage right in the office with the aid of some application software such as ArcGIS [6]. A thorough integrated site investigation with an office design can enhance the efficiency, profitability and effectiveness of mitigation against unacceptable environmental impacts.

During dredging operation, hydrographic survey is carried out by the Geomaticians in order to determine the three dimensional coordinates, which provide the basic geospatial data sets for the volume computation and vertical levels of the sea bed, thereby, the volume of materials to be excavated. The hydrographic surveys of dredging project can be divided into three groups: pre-dredge, progress or interim, and postdredge surveys[10].

Pre-dredge surveys are the preliminary surveys conducted before the start of the dredging project. The progress survey, as the name implies, is the monitoring of the volume of excavated material during dredging and it is often used to estimate payment. The need for an accurate and properly executed baseline (pre-dredge) survey is critical to reducing the potential for disputes about payment volumes [11].The post-dredge survey is the final survey carried out after the completion of the dredging project so as to ensure that all materials have been removed and the design depth has been achieved. Both pre- and 
post-dredged surveys must be carried out by Geomatics Engineer in order to determine the quantum of sand material that was dredged [12].

\subsection{Volume Computation}

Accurate estimation of dredged volume is a very important aspect of dredging. This is because volume computation is the only way to monitor the dredging process, thereby comparing the amount of materials planned to be dredged and the amount that was actually dredged [6]. Different methods have been adopted for computing dredged volume. Most of these methods depend on area of cross sections, Triangulated Irregular Network, and regular grids based on digital elevation models [10]. The end are a method of computing volume is applied in these methods. All commonly used volume computation methods are reduced to that used in determining the area bounded by a finite group of data points and projecting this area over some length to obtain a prismoidal volume. The area can be projected vertically or horizontally as shown in the following equations.

The average end area technique for horizontal projection:

$$
V=\frac{1}{2}\left(\mathrm{~A}_{1}+\mathrm{A}_{2}\right) \times \mathrm{L}
$$

In (1), $V$ is the volume, $A_{1}$ and $A_{2}$ is the Cross sections of the areas, and $L$ is the Distance between areas $A_{1}$ and $\mathrm{A}_{2}$.

Bin/grid technique for vertical projection,

$$
V=H+A
$$

Here, $\mathrm{V}$ is the volume of the grid, $\mathrm{H}$ is the elevation of the depth above or below the reference surface and $\mathrm{A}$ $=$ cell Area on the reference frame. TIN technique for vertical projection using:

$$
V=\frac{1}{3}\left(\mathrm{~h}_{1}+\mathrm{h}_{2}+\mathrm{h}_{3}\right) \times \mathrm{A}_{0}
$$

In (3), $h$ is the height of vertices above design (pay) prism and $A_{0}$ is the triangular area of prismoidal element projected on design surface.

Over the years, various automated methods have been used for computing dredged quantities. For instance, the end area may be computed using trapezoidal elements, coordinate/ double meridian distance (DMD) areas, or numerical integration. The Triangulated Irregular Network (TIN), which is a set of triangles covering the require area with no overlapping, provides a better picture of the channel. Volume computed from the same data with the TIN model is also more accurate when compared with the volume computed using average end technique [13].
Also, TIN technique offers an effective method of processing volume from data obtained from the multibeam system. The volume of the dredged sediments can also be computed using ArcGIS by ESRI, using TIN differences tool in 3D analyst and Surfer software packages, provided the bathymetric data is available. The availability of HYPACK software can also be used for volume computation using any of the above techniques [14].

The accuracy of a resultant volume is dependent on many random variables, such as the horizontal positioning accuracy, elevation (or depth) measurement accuracy, data density or personified footprint size relative to the overall area, terrain uniformity, and the volume computational method employed [13].

\section{METHODOLOGY}

Multi beam echo sounder was used to obtain the depth data understudy. One of the greatest benefits of using multi beam echo sounder is that it gives full bottom coverage of the water body, thereby providing a much accurate knowledge of the seafloor making it possible to detect all objects beneath the water and area not to be dredged will be clearly identified. Information between the normal cross-sections can also be obtained using the multi beam system. The DGPS in the real time kinematic (RTK) mode was used alongside with the multi beam echo sounder to determine the height of the boat from which the soundings were taken. The mounting of DGPS on the survey vessel along with the multi beam echo sounder is shown in Figure 1.

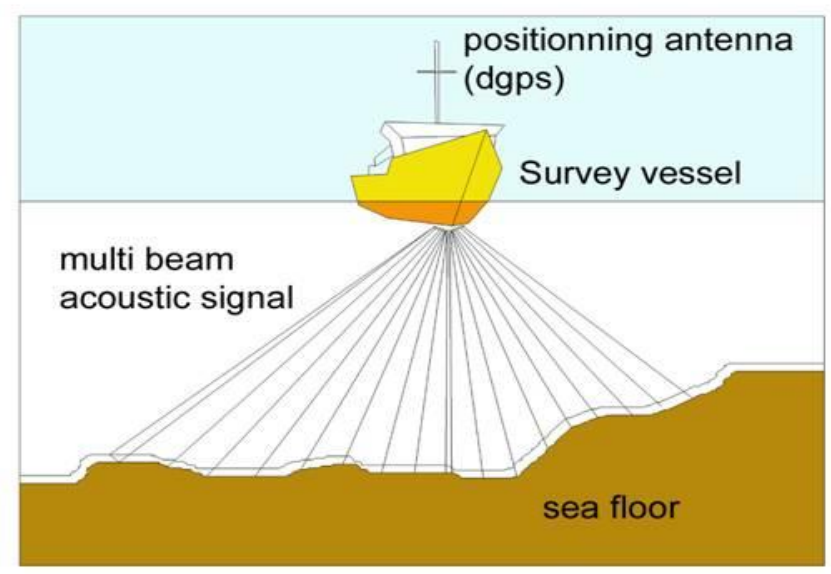

Figure1: Data Acquisition using Multibeam and GNSS

Some of the importance of measuring the height of the boat is that it will eliminate $[14,10]$ : 
$>$ Measuring tidal height using tide gauge including making any allowance for the time and range difference between the tide at the recording station and at the survey site

$>$ Measuring heave (vertical rise and fall of the vessel due to swell and wave action)

$>$ Squatting (vertical rise or fall of the vessel due to changing hydrostatic pressure around the hull as the boat moves through the water)

$>$ Measuring vessel motion along multiple axes.

\subsection{Pre- and Post-Dredged Surveys, 3-D Surfaces and Contour Maps}

In the pre-dredged survey, observations were carried out over a very large area, about 2.3 hectares, beyond the required dredging point. This was taken into consideration so as to cover all the dredged points and also where necessary areas to avoid during the dredge operations. After the dredging operation was completed, a post dredged survey was conducted using the same equipment and the area and volume from each case were computed using the data sets acquired. Both surveys were plotted in AutoCAD environment and the dredged area was extracted from the pre-dredged survey in order to calculate the pilestock of the dredged material. The 3D surfaces of both the pre-dredged and post-dredged surveys data were generated using Surfer 8 Golden software as shown in Figure 2. The contours of both pre- and post-dredged surveys were also plotted in Surfer 8 software environment.

\section{RESULTS AND DISCUSSION}

The total area of the pre-dredged survey covering the study area as extracted in AutoCAD environment is $9553 \mathrm{~m}$ while that of post-dredged is $9563 \mathrm{~m}^{2}$.The minimum height of the pre-dredged survey is $9.21 \mathrm{~m}$ and the maximum height is $10.26 \mathrm{~m}$ while for the postdredged survey, the minimum height is $8.49 \mathrm{~m}$ and the maximum height is $18.65 \mathrm{~m}$. The pre-dredged survey contour was plotted at interval of $0.05 \mathrm{~m}$ and the postdredged survey was plotted at interval of $0.5 \mathrm{~m}$. The contour maps are shown in Figure 3.

Simpson's rule volume is $94243.461 \mathrm{~m}^{3}$ and the net volume is $94243.456 \mathrm{~m}^{3}$. Also, for the post-dredged survey the volume from Trapezoidal rule is $103975.472 \mathrm{~m}^{3}$, Simpson's rule is $103980.029 \mathrm{~m}^{3}$ and the net volume is $103975.435 \mathrm{~m}^{3}$. The volume of the stockpile computed from the pre- and post-dredged surveys using the net volume is $9731.979 \mathrm{~m}^{3}$.

The volume computation reports as computed, using Surfer 8 software, is shown in Table 1 and Table 2.From the volume computation reports, the total volume of the surveys were computed using Trapezoidal rule, Simpson's rule and net volume was also computed. The volume of the pre-dredged survey was computed over an area of $9553 \mathrm{~m}^{2}$ of 51 survey points while the volume for the post-dredged survey was computed over an area of $9563 \mathrm{~m}^{2}$ of 189 survey points. For the pre-dredged survey, the Trapezoidal rule volume is $94243.408 \mathrm{~m}^{3}$,
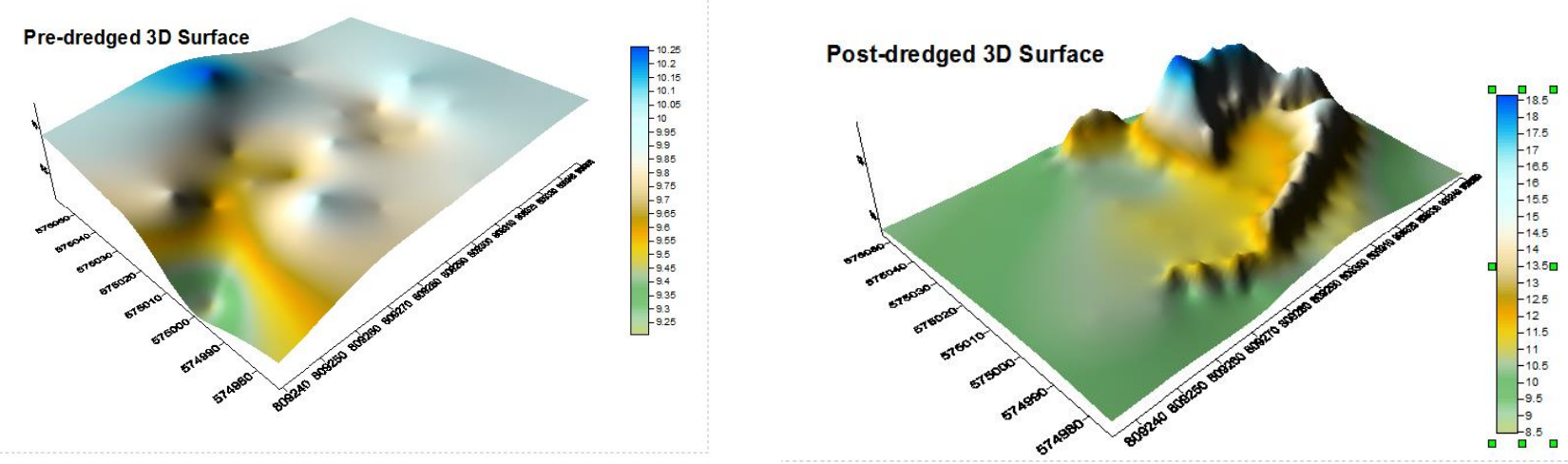

Figure 2: Pre-dredged and Post-dredged 3-Dimensional Surfaces

Table 1: Pre-dredged Volume

\begin{tabular}{l|l|l|l}
\hline $\mathrm{X}$ Coordinates $(\mathrm{m})$ & Y Coordinates $(\mathrm{m})$ & Z Coordinates $(\mathrm{m})$ & Volumes $\left(\mathrm{m}^{3}\right)$ \\
\hline $\mathrm{x}($ minimum $): 809239$ & $\mathrm{y}($ minimum $): 574973$ & $\mathrm{z}($ minimum $): 9.208$ & Trapezoidal Rule:94243.408 \\
$\mathrm{x}$ (maximum):809350 & $\mathrm{y}$ (maximum):575059 & $\mathrm{z}$ (maximum):10.264 & Simpson's Rule:94243.461 \\
$\mathrm{x}$ (spacing): 1.118 & $\mathrm{y}$ (spacing): 1.120 & & Net Volume: 94243.456 \\
\hline
\end{tabular}


Table 2: Post-dredged Volume

\begin{tabular}{|c|c|c|c|}
\hline $\mathrm{X}$ Coordinates $(\mathrm{m})$ & Y Coordinates $(\mathrm{m})$ & Z Coordinates $(\mathrm{m})$ & Volumes $\left(\mathrm{m}^{3}\right)$ \\
\hline $\mathrm{x}($ minimum): 809239 & $\mathrm{y}($ minimum): 574973 & $\mathrm{z}($ minimum $): 8.489$ & Trapezoidal Rule:103975.472 \\
\hline$x($ maximum $): 809350$ & $y($ maximum):575059 & $\mathrm{z}($ maximum $): 18.651$ & Simpson's Rule:103980.029 \\
\hline $\mathrm{x}$ (spacing): 1.169 & $y$ (spacing): 1.1740 & & Net Volume: 103975.435 \\
\hline
\end{tabular}
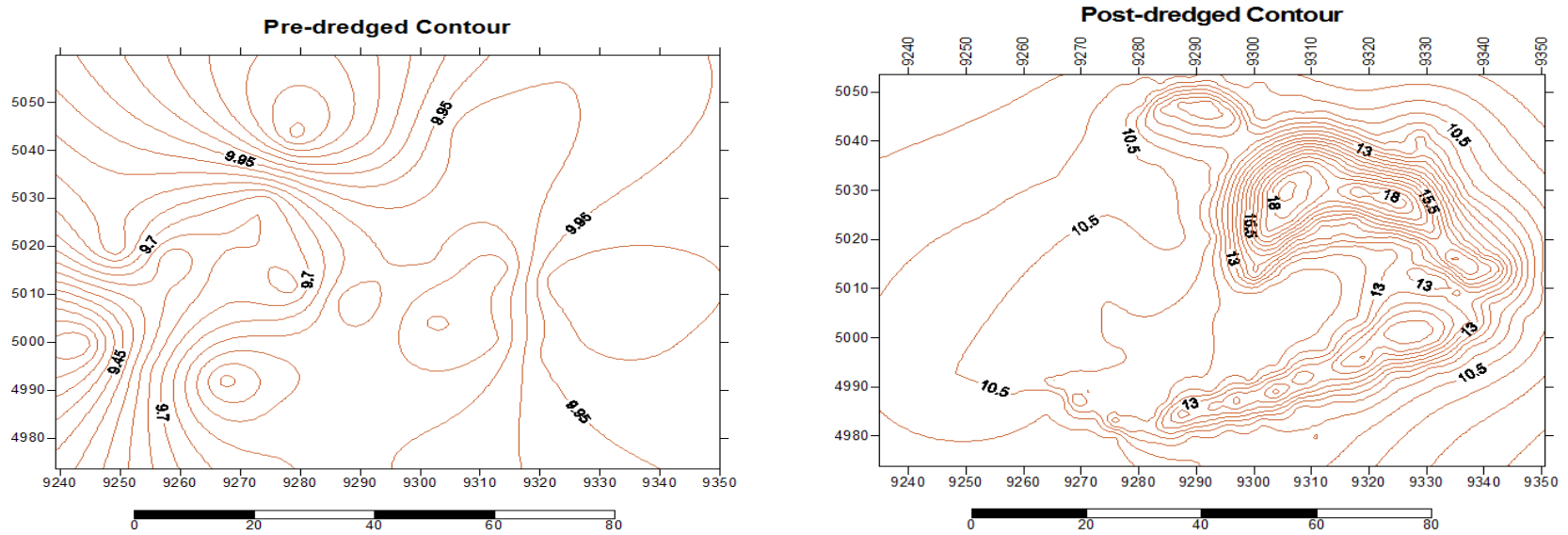

Figure 3: Pre- and Post-dredged Contour Maps
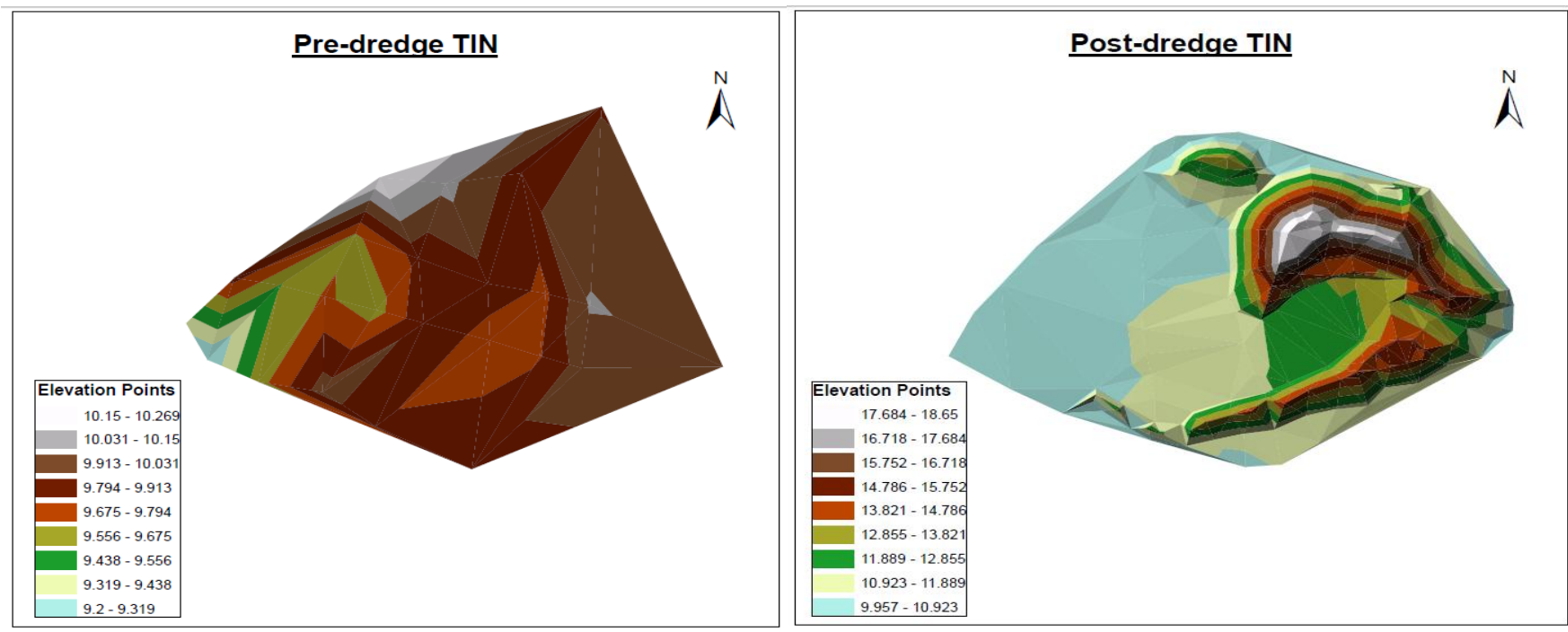

Figure 4: Triangulated Irregular Network (TIN) of Pre-and Post-dredged Surveys

The lowest elevation point of the pre-dredged TIN is $9.20 \mathrm{~m}$ and the highest point is $10.27 \mathrm{~m}$. While the lowest elevation point of the post-dredged TIN is $9.97 \mathrm{~m}$ and the highest point is $18.65 \mathrm{~m}$. These are shown in Figure 4.

\section{CONCLUSION}

During dredging operation, the determination of the volume of stockpile of the dredged materials is very important in order to estimate the quantity of deposited materials, the extent of the excavation and for purpose of costing. To achieve this, the predredged and post-dredged surveys were carried out. The volume of the stockpile was thereby computed from the difference in calculated volume of pre- and post-dredged surveys.

\section{REFERENCES}

[1] United States Environmental Protection Agency (USEPA) "Case Studies of Environmental Dredging Projects" Draft Engineering Performance Data Public Review Copy Vol. 4, Number 4, Prepared by Malcolm Pirnie, Inc. and TAMS Consultants, Inc. (2003).

[2] National Oceanic and Atmospheric Administrator, (NOAA) "What is Dredging" http://oceanservice.noaa.gov/facts/dredging.htmlA ccessed on August 04, (2015).

[3] Richbom Group Nigeria "Dredging and Commercial Sand Production in Nigeria; the Opportunity" 
https://richbomgroup.wordpress.com Accessed on July 13, (2016).

[4] National Inland Waterways (NIWA) Act No 13 of 1997: Laws of the Federation of Nigeria http://www.nigeria-law.org Accessed on July 14, (2016).

[5] Foraminifera Market Research "Dredging and Sand Stock Piling in Nigeria: How Viable?"

http://www.foraminifera.com Accessed on July 13, (2016).

[6] Sandiford, R. and Dunlop, P. "Best Practices: Dredging and Dredged Material Disposal" 2013 ftp://dfi.org Accessed on August 11, (2015).

[7] "Dredging: The Facts" http://www.iadcdredging.com Accessed on August 11, (2015).

[8] Owen, T. and Park K. "Dredging" www.engr.colostate.edu Accessed on August 15, (2015).

[9] Interstate Technology and Regulatory Council (ITRC) "Contaminated Sediments Remediation" Remedy Selection for Contaminated Sediments Guidance Document http://www.itrcweb.org Accessed on August 04 (2015)

[10] Rabah, M., Zeidan., Z. and Zhran, M."Study the Effect of Measured Heave in Single Beam Hydrographic
Survey on Dredged Quantity Estimation" Journal of Environment and Earth Science Vol. 5. Number 14, (2015).

[11] Dinicola, W. J., Merrittis, T. W., Hayward, C. A. and Mohan, R. K. "Best Practices for Dredging and Sediment Management at Inland Lakes" WEDA Journal of Dredging Vol. 14, Number 2, , Pp 16-36. (2014).

[12] Etuonovbe, A. K. "Economic Benefit of Hydrography: Land Reclamation in Bayelsa State -A Case Study of Saipem Camp" FIG Publication 57, (2010).

[13] International Hydrographic Organization (IHO) "Standard for Hydrographic Surveys- Special Publication" Number 44, 5th Edition Published by the International Hydrographic Bureau, MONACO 2008. http://www.docfoc.com Accessed on August 04 (2015).

[14] Aliyu, A., Orisakwe, K. U. and Sakinzango, K. "Bathymetric Survey for the Dredging of San Bartholomew River in Akukutoru Local Government Area of Rivers State, Nigeria" Journal of Sciences and Multidisciplinary Research, Vol. 5, Number 2, , Pp. 10 - 18. (2013).

[15] Rabah, M. "Using RTK tides in The Northern Coast of Egypt, Undulation Model Correction Derived from EGM 2008" The Journal of The Institution of Civil Engineering Surveyors, Vol. 9, Number 1, (2009). 